\title{
Duffing Up the Criminal Law?
}

\section{Patrick Tomlin ${ }^{1}$}

Published online: 18 October 2019

(c) The Author(s) 2019

\begin{abstract}
R.A. Duff's The Realm of the Criminal Law advances the literature on criminalization by providing the most thorough exploration and defence yet provided of the intuitively attractive idea that criminalization is properly limited to public wrongs only. I outline here six concerns I have with the view, as presented in this book, and suggest where the account needs further elaboration, defence, or rethinking.
\end{abstract}

Keywords Duff $\cdot$ Criminalization $\cdot$ Public wrongs $\cdot$ Legal moralism

\section{Introduction}

I am tremendously honoured to be asked to participate in this symposium on Antony Duff's The Realm of Criminal Law. The international community of criminal law theory owes Antony a huge debt. He is not only one of the preeminent scholars in this field, he has also done so much to build and shape it as a community. The Realm of Criminal Law Theory is a civil order in which Antony has played a leading role. And while Antony's politics are avowedly egalitarian, academic esteem is not, and he is surely one of the high priests of that community.

The central idea that The Realm of Criminal Law seeks to explore and defendthat the proper scope of criminal law is limited to 'public wrongs'-is a powerful and intuitively attractive one. But it is also one that is hard to pin down. The idea, attractive as it is, seems to swing between something close to empty, and something close to scary. At the empty end, it can feel as if it swings a little too close to "we

\footnotetext{
I am grateful to Antony Duff, Victor Tadros, Alec Walen, and all who attended the conference at Rutgers in May 2019 for useful feedback and discussion. A word on the title: 'Duff' in colloquial British English carries at least three distinct meanings: 'duff'—defective; 'duff up' — to beat up; and 'up the duff' - to be pregnant. Antony's name means that a pun-based title is essential. I should have thought of a better one though.

For special issue on R.A. Duff, The Realm of Criminal Law.
}

Patrick Tomlin

Patrick.tomlin@warwick.ac.uk

1 University of Warwick, Coventry, UK 
should only criminalize what we ought to criminalize.' So formal as to be just about empty. At the scary end, 'public wrongs' seems so permissive as to provide hardly any brakes on the criminalization process at all-if we think something is 'our' business, we can criminalize it. This hardly offers us the principled bulwark against overcriminalization that we seek. ${ }^{1}$

This book develops, explains, argues for, and replies to criticisms of the view in ways that renders it much clearer and more convincing than previous iterations. I, for one, now have a much better sense of what the view can do, and where it is coming from. But the book is also candid about what the view cannot do. The concept of public wrongs is not empty, but it is 'thin'. It is not a substantive view of criminalization. Rather, it can structure debate about criminalization.

That said, I do, of course, have remaining, and new, worries about the view. In this paper, I will seek to explain six concerns I have about the view as presented in The Realm of Criminal Law. Briefly, these are as follows:

1. There is an ambiguity in the central principles of criminalization for which Duff argues. There are two different interpretations of Duff's principles of criminalization-an ambitious reading and a modest reading. I show that Duff favours the ambitious reading.

2. I argue that Duff is wrong to go for the ambitious reading. This leads to an unhelpful structuring of debates around criminalization: criminalization becomes the 'default' response to public wrongs. In order to escape this conclusion, Duff would need to admit that his theory is not really a theory of criminalization.

3. Duff's principles of criminalization as stated give us reason to criminalize minor public wrongs, like queue-jumping. His defence of this seems inconsistent with his rejection of expansive legal moralism, as defended by Michael Moore.

4. Duff delineates two complaints against criminalization that arise from the public wrongs account: that the conduct isn't wrong, and the conduct isn't public. I think the second complaint is too simply stated. These considerations lead us to two interpretations of Duff's Principle B, based around descriptive and normative accounts of what counts as 'public'.

5. The above interpretive question, about the concept of 'public', in turn raises the question of what the theory is a theory of: what is unjust criminalization and what, normatively, follows from it? Without answering these questions, it is hard to evaluate the theory.

6. The concept of 'public wrongs' seems to play three distinct roles within the book. There is a danger that this renders the argument circular.

\section{Duff's Principles: A Modest and an Ambitious Reading}

Duff's book argues for two principles of criminalization:

1 Douglas N. Husak, Overcriminalization (New York: Oxford University Press), ch. 1. 
A. We have reason to criminalize a type of conduct if, and only if, it constitutes a public wrong.

B. A type of conduct constitutes a public wrong if, and only if, it violates the polity's civil order. ${ }^{2}$

In order to fully understand these principles, we will need to know more about the following: what does 'criminalizing conduct' entail?; what is a 'public wrong'?; and what is a polity's 'civil order'? I will return to all of these later in this paper, though much of Duff's book is spent investigating and clarifying these issues.

In one sense, Duff's principles appear to be exhaustive. Principle A is an 'if and only if' principle - it gives a necessary and sufficient condition for having reason to criminalize a type of conduct. And Principle B offers us a necessary and sufficient condition of what it is for something to be a public wrong.

But notice that whilst Duff's principles seem exhaustive in one way, in another they are quite modest. They concentrate (through Principle A) on what gives us a reason to criminalize. We only have reasons to criminalize public wrongs, but it doesn't follow that Principle A gives us a necessary and sufficient condition for permissible criminalization. Once we have a public wrong we know, according to Principle A, that we have reason to criminalize. But that doesn't mean that we must, or that it would be good to, or even that it is permissible to, criminalize that public wrong.

Principle A, as stated, is open to two alternative readings. I'll show that Duff appears to endorse one, but in the next section I will argue that he ought to endorse the other. The two readings emerge because of an ambiguity concerning what Principle A is supposed to provide us with: does it only specify what kinds of conduct we have reason to criminalize, or does it also concern what reasons we have to criminalize that conduct?

Here are the two alternative readings:

Reading 1 (the modest reading): Principle A specifies what types of conduct we have reasons for criminalizing, but not our reasons for criminalization. We only have reason to criminalize public wrongs, but that they are public wrongs does not necessarily exhaust the reasons we have for criminalizing them.

Reading 2 (the ambitious reading): Principle A specifies not only what kinds of conduct we have reason to criminalize, but also our reasons for criminalizing them. We only have reason to criminalize public wrongs, and our only reason for criminalizing them is that they are public wrongs.

Principle A, read strictly, only implies the modest reading. But Duff makes it clear he has the ambitious reading in mind - just after one of the central statements of the

\footnotetext{
2 R.A. Duff, The Realm of Criminal Law (Oxford: Oxford University Press, 2018). The principles are first introduced at p. 232, and repeated several times thereafter.
} 
principles, he clarifies: 'the only good reason to criminalize a type of conduct is that it constitutes a public wrong., 3

Here is Principle A rewritten to reflect this ambitious reading:

Ambitious A: We have reason to criminalize a type of conduct if, only if, and because, it constitutes a public wrong.

Neither Modest A (as I will refer to the original Principle A), nor Ambitious A imply that we ought to criminalize all public wrongs. Modest A leaves open the idea that we might have reasons other than something being a public wrong to criminalize some conduct (although those reasons could only apply to public wrongs). Ambitious A does not allow for these reasons - there are no reasons to criminalize conduct other than that it is a public wrong. But it does allow that there can be countervailing reasons not to criminalize conduct, even if it is a public wrong.

Duff is clear that we should not criminalize all public wrongs. He states:

To say that something constitutes a public wrong is to say that it is our collective business as a polity: it is something to which we have the standing, and might have a responsibility, to respond; and an appropriate response to a wrong is to mark it as a wrong and to call its perpetrator to account.

However, this is so far to say only that criminalization is an appropriate response to a public wrong, not that it is the appropriate response. We might have some reason to criminalize every kind of public wrong, in that criminalization constitutes one possible response. But it is not the only possible response...our question must therefore be not simply whether we have reasons to criminalize, as if our choice was between criminalizing and doing nothing, but whether we have reason to criminalize rather than responding in some other way. 4

\section{The Ambitious Reading and Criminalization as the Default}

Duff's book is avowedly modest in terms of its concrete proposals. Duff shies away from trying to tell us exactly what we should and shouldn't criminalize, and not only because such conversations inevitably involve the kinds of complex empirical investigations which philosophers are notoriously bad at. What Duff hopes to do, above all else, is to structure deliberation about criminalization. ${ }^{5}$ I want to suggest here that Ambitious A unduly limits the kinds of reasons we can offer when considering whether or not to criminalize some conduct, and that it places the criminal law in an unfortunately prominent position when considering how to respond to certain forms of wrongdoing: it becomes the default. Ambitious A therefore unhelpfully distorts

\footnotetext{
3 P. 277. Emphasis in original.

${ }^{4}$ P. 278. Various other potential responses to public wrongs are laid out in ch. 7.

5 P. 53 (and throughout).
} 
public discourse on criminalization. This, I think, is an important criticism on the theory's own terms, since one of its primary aims is to structure discourse.

Ambitious A has these three implications. First, any and all 'public wrongs' are wrongs we have some reason to criminalize. Second, we have no reason to criminalize anything that isn't a public wrong. Third (where Ambitious A is distinctive from Modest A), the only reason we have to criminalize conduct is that it is a public wrong.

Let's imagine we have found a public wrong. To use an example of Duff's, imagine we recognise queue-jumping as a public wrong. ${ }^{6}$ It's wrong, and it's wrong in a way that violates the civil order. Now, we have to decide how, as a political community, to respond to this wrong. Duff offers a huge range of potential responses, ranging from 'nothing' through to 'criminalize' and 'criminalize and punish' (these last two are importantly different for Duff). Which option should we go for?

According to Ambitious A, we can only offer reasons against criminalization. We cannot offer any reasons for criminalization, for we already have the one and only such reason we could have-this is a public wrong. And since we cannot offer any reasons for criminalization, conduct that is a public wrong is not only potentially criminalizable, it is presumptively so: we must now offer reasons against its criminalization, and if we do not, we must criminalize. Criminalization becomes the default option for all public wrongs. This unhelpfully structures public debate in favour of criminalization - once we have a public wrong nothing else can be said, and so nothing else need be said, in favour of criminalization.

This is a reason in favour of Modest A over Ambitious A. Modest A limits criminalization to public wrongs only, but it does not claim that some conduct's public wrongfulness is the only reason that can be offered in favour of its criminalization. Indeed, on Modest A, we could demand that, once we have established something is a public wrong, further reasons must be offered in favour of criminalization: some conduct being a public wrong is necessary and sufficient to have reason to criminalize, but it is not sufficient reason to criminalize.

An alternative would be to alter Ambitious A so that was not a principle of criminalization but rather a principle of public (or perhaps official) response. A conduct's public wrongfulness would then be the only reason that could warrant a public response, and criminalization, as a species of such a response, would then be on the table. However, further reasons may need to be offered in its favour-we would need to argue in favour of criminalization as the appropriate public response, not merely assume it is the default response.

This is in fact how Duff sometimes appears to understand Principle A. In his discussion of queue-jumping, Duff writes:

If queue-jumping is a public wrong, on my account we have reason to ensure that it receives an appropriate public response-that those who engage in it are suitably (proportionately) held to account for it. Criminalization seems to

\footnotetext{
${ }^{6}$ Pp. 280-282.
} 
be one way in which we can provide for such a response: we therefore, we could say, have reason to consider criminalizing queue-jumping. However... we might indeed say that we have no reason to criminalize queue-jumping. ${ }^{7}$

This is plausible normatively. But this doesn't seem plausible as a reading of Principle A. It is not, as stated, a principle of public response, or a principle concerning what we have reason to consider criminalizing. It is a principle concerning what we have reason to criminalize. If queue-jumping is a public wrong, we have good reason to criminalize it. In order to say we have no reason to criminalize queue-jumping, we should change Principle A to be a principle concerning public response. We'd have reason to respond to queue-jumping, but we'd then need independent principles of criminalization which explain when it would be a good idea to use this particular public response.

But if this is the right way to read Duff's theory, it is, crucially, not a theory of criminalization. It is a theory of public response. It's a theory of what we have reason to consider criminalizing, not a theory of what we have reason to criminalize. The Realm of Public Response would have been a better title for the book in that case.

\section{Reasons to Criminalize Minor Public Wrongs? Duff Versus Moore}

Even though Duff sometimes implies that his theory is actually a theory of public response, elsewhere he seems to interpret his principles as principles of criminalization. In doing so, he admits that we do have reason to criminalize queue-jumping. Some may find this concerning, but Duff reminds us that 'having a reason to do $\mathrm{x}$ ' does not imply that we ought, all things considered, to do x: Our reason to criminalize queue-jumping is 'clearly not a good enough reason, or even a strong reason; but it is a reason to criminalize. ${ }^{8}$ Let's call this the 'It's Just A Reason' (IJAR) response.

First, note, for reasons articulated above, on Ambitious A we have more than 'just a reason.' We have the reason to criminalize. It's a presumptive reason. So it is hard to see why it wouldn't be a strong reason to criminalize (though not strong enough). But clearly, according to both Ambitious A and Modest A, it's a defeasible reason.

I won't, here, try to evaluate the IJAR response. Perhaps we have reasons to do all sorts of weird or clearly wrongful things, and so it's really no big deal to say we 'have a reason' to criminalize queue-jumping. In which case, the force of Principle A is quite weak. On the other hand, it seems odd to say there's anything to be said in favour of criminalizing queue-jumping.

The claim I want to make here is that Duff's use of the IJAR response seems in tension with his arguments against other theories which purport to offer a (or the) reason to criminalize, since those arguments appear to reject the IJAR response. Consider Duff's objection to Michael Moore's expansive legal moralism, which

\footnotetext{
7 P. 281.

8 P. 281.
} 
gives us reason to criminalize all moral wrongdoing, including apparently private matters like extra-marital affairs, lying, and so on:

The fact remains...that on Moore's account we have good reason to criminalize every kind of moral wrongdoing - even if that reason is quite often outweighed or defeated by reasons against criminalization: but it does seem very odd to say that we have any reason at all to criminalize my betrayal of my partner or my friend - or my failure to buy my round in the pub, which is surely a breach of the (modest but still real) obligations that partly define that type of social interaction. ${ }^{9}$

Recall, Duff's view says we have reason to criminalize queue-jumping. Duff says, well yes, but that doesn't mean we should do it. It's just a reason. And yet when Duff rejects Moore, Duff says the IJAR response won't do. It's not enough that we won't end up criminalizing extra-marital affairs, we don't have any reason at all to do so.

The IJAR response seems an equally adequate response for both Duff and for Moore, or an equally inadequate one. For it seems just as counter-intuitive to say that there's a reason to criminalize affairs as there is to say there's a reason to criminalize queue-jumping. Duff would no doubt emphasise that there's a sense in which queue-jumping is 'our' business, whilst affairs are the business of the couple, and maybe some close relatives and friends. Perhaps my scepticism is that I don't buy that queue-jumping is a public matter: there's a practice of queueing, but there's also a practice of marriage and of monogamous relationships. Just because there's a publicly-recognised practice, it doesn't make violations of that practice a public matter (marriage is also a publicly recognised practice). Jumping the queue may only be the business of the people in that particular queue.

This response might be quite friendly to Duff: I just deny either affairs or queue-jumping are public matters, so of course I wouldn't see any difference between offering a reason to criminalize either. And Duff, of course, recognises that there's plenty of room for reasonable disagreement on what is and isn't a 'public wrong.' So this would just challenge one particular categorisation of something as 'public.'

But I wonder if there's a deeper problem here. Duff draws one big line between what is 'our' business as citizens, and what is not. Public wrongs are our business, and so are potentially criminalizable, and there is reason to criminalize them. Affairs are not our business, and so it seems wrong to say that they are even potentially criminalizable, or that there is any reason to criminalize them. Within the potentially criminalizable, we might make further distinctions around what should be handled by the criminal law, what should be handled by public disapproval, and so on. But Duff seems to view these lines as much lighter lines, compared to the big red one between 'public' and 'private.' Once we know we're in the business of public wrongs, we have some choices to make, but the main thing to establish is whether or

\footnotetext{
9 P. 74.
} 
not something is a public wrong. (After all, that's the only reason that can be offered for criminalization).

Yet I would argue that these lines, those within the public sphere, are just as important to us. In particular, the line between civil society and government is important. There is wrongdoing that can be in the public interest in some sense, but it can still be completely inappropriate for governmental or official sanction. Consider the 'private' wrongdoing of politicians. Sometimes this wrongdoing (as wrongdoing) is in the public interest, and so it is held to be, in some sense, 'our business.' And yet it would be wildly inappropriate for the government or state to officially sanction that wrongdoing. Duff's notion of the 'public' sees little difference between civil society and the government. However, this distinction seems very important, such that it seems just as strange to say that there is reason to criminalize queue-jumping, even if it is public, as it does to say the same about affairs. Queuejumping might be our business, but that doesn't make it state business, and crime needs to be state business.

Maybe it's fine to say there's reason to criminalize queue-jumping, even though we would never dream of criminalizing it. Maybe it's just a reason. But I remain confused as to why Moore can't say the same about extra-marital affairs.

\title{
5 Not Your Business: Complaints Against Criminalization and the Concept of 'Public'?
}

\author{
Recall Principle A (or Moderate A as I have renamed it):
}

A. We have reason to criminalize a type of conduct if, and only if, it constitutes a public wrong.

Criminalization that violates Moderate A gives rise to complaints. Duff argues we get two distinct, complaints against some conduct having been criminalized, or some claim that some conduct ought to be criminalized, from Principle A. ${ }^{10}$ The first complaint is: but that conduct isn't wrong. For Duff, only wrongful conduct may be criminalized. This is what Duff usefully distinguishes as Negative Legal Moralism.

The second complaint is that, even if the conduct is wrongful, it may not be public. That is, a citizen might say, 'Yes! My conduct is wrong. But it's none of your business-it does not concern us as citizens. It does not threaten our civil order.' This notion of what makes conduct public is central to the account, and the book does much to define and to help us to understand this notion.

The above discussion about public wrongs that are nevertheless not criminalizable, such as queue-jumping, allow us to add two further complaints about conduct that is criminalized. These are related to the 'that's not public' complaint, but are distinct from it: they are 'that's not the law's business,' and 'that's not the criminal law's business.' We can make a complaint that, yes, this is wrong, yes this is a public wrong, but, actually, it should not have been criminalized. This could be either

${ }^{10}$ P. 278. 
because it is not the law's business, or because it's not the criminal law's business, and should be handled by some other area of law.

The second further complaint is what we can call the 'wrong civil order' complaint. This is a version of the 'not public' complaint, but it is useful to distinguish between two different versions of that complaint. One version is: 'Hey! Round here we don't take that to be our business!'- that is, the conduct in question does not violate the community's civil order, as they have constructed it. Call this the Descriptive Version, since the complaint invokes the civil order as we find it. The other is: 'Hey! Yes, round here you take that to be your business. But you shouldn't!' Call this the Normative Version, since the complaint invokes the civil order as it should be.

Duff is interested in the civil order both descriptively and normatively. ${ }^{11}$ Descriptively, the civil order is a rational reconstruction of local political norms and values about what is our business. Normatively, the civil order is the civil order we ought to have.

There is an important interpretive question here about which of these understandings is relevant in interpreting Principle B, which, recall, defines a 'public wrong' as conduct that 'violates a polity's civil order.' Is conduct criminalizable because it is wrong and is within our local understanding of what is our business; or because it is wrong and is within the right, or best, or an acceptable understanding of what is our business? Or is only criminalizable if it falls within both?

At one point Duff states that 'in the end' his concern is with 'a normative account of the public realm.' ${ }^{12}$ And Duff does sometimes allow that we might say 'yes, round here this is public, but it shouldn't be. ${ }^{, 13}$ Duff is clear that people can object to a civil order. They can criticise it, and, by extension, criminal laws made off the back of it. ${ }^{14}$ But it's not clear whether such laws can violate Principles A and B, or whether the complaint to be made is of a different nature. If Principles A and B are principles of just criminalization, are criminal laws which criminalize wrongs that are only public due to a morally deficient civil order unjust laws? Or are they just laws that can be criticised on some other basis?

Duff is not only interested in ideal political theory-he also wants to respect the communities that have been constructed. He often appears to suggest that what makes some conduct properly criminalizable is that it is (a) wrongful; and (b) violates our civil order (i.e., the descriptive civil order). For instance, he says that the liberal republican view he sketches is just an example, not a claim about what polities ought to look like. ${ }^{15}$ He sometimes implies that we ought not to complain about local norms around what is public, since what makes them public is contextdriven. ${ }^{16}$ The civil order is 'structured by the set of goals and values through which

\footnotetext{
11 P. 162.

12 P. 163.

13 See R v. Brown example on p. 162. See p. 166.

14 P. 166.

15 Pp. 5-6.

16 See example of gardens on p. 162, where it would be 'inappropriate' when challenged on the state of my garden to tell others that it is 'not their business' if there was a community norm of taking interest in the state of each other's gardens.
} 
a polity constitutes itself. ${ }^{17}$ Duff wants to allow that we can criticise civil orders, but also that there is a modest form of pluralism or relativism built into the public wrongs account: 'By linking criminal law to civil order, and insisting (as democrats must) that it is for the polity's members to work out their conception of their civil order, I do open the door to a modest kind of pluralism. ${ }^{18}$

Although he claims his interest is 'in the end' normative, Duff gives serious weight to local positive civil orders. So, it seems, both matter in some way. But, as I say, what is not clear is how Principles A and B should be interpreted. Here, then, are three different ways of interpreting Duff's Principles A and B:

Interpretation 1. Normative Only. Principles A and B refer to the best (or acceptable) understandings of the civil order. As with wrongs, local beliefs are irrelevant.

Interpretation 2. Positive Only. Principles A and B refer to the local, positive civil order. There is always good reason to criminalize wrongful conduct that violates the civil order we actually have. (However, it is an independent reason against criminalization, that it is not the correct, or is an unacceptable, or unreasonable, civil order).

Interpretation 3. Both Positive and Normative. Principles A and B refer to both, the local, positive, civil order, and the normative civil order. There is only reason to criminalize wrongful conduct if it violates our civil order and that civil order is the correct one (or an acceptable one).

Interpretation 1 is not plausible as an interpretation of Duff. However, this reveals something interesting. Duff is anti-relativist when it comes to 'wrongs.' He deals with Devlin's 'positive legal moralism' very quickly. Devlin's view is that a society may criminalize homosexual sex if they think that that's wrong. But that doesn't matter, says Duff. What matters is whether it is wrong. ${ }^{19}$ In contrast, when it comes to the civil order, Duff is a moderate relativist. It matters what we take to be our business, perhaps even if we're wrong about that. In other words, Duff seems to treat moral and political theory differently. Moral demands on individuals are, if not universal, then certainly cross-polity, and pre-political. What is wrong is not a local matter. But demands on polities, on how they treat individuals, are, to some extent at least, a local matter. There is only one true morality, but there is reasonable pluralism when it comes to constructing the civil order.

Why the double standard? Why can we not plausibly insist that there is just one right conception of the civil order (even though there is reasonable disagreement about it), ${ }^{20}$ but we can plausibly insist that there is just one right conception of interpersonal morality (about which there is reasonable disagreement)? Does a society have no 'right to be wrong' about individual morality, but a 'right to be wrong'

\footnotetext{
17 P. 7. My emphasis.

18 P. 232. See also pp. 54, 125.

19 Pp. 53-55.

20 P. 232.
} 
about political morality? Or is political morality less specific than individual morality, allowing for greater flexibility? Why should my non-wrongful conduct never be justly criminalized, but my incorrectly 'publicised' conduct may be ? $^{21}$

The difference between Interpretation 2 and Interpretation 3 comes about when a polity has a sub-optimal (or maybe unacceptable) civil order, and so a faulty sense of what is its business. It can be criticized. But does it have (defeasible) reasons to criminalize wrongful conduct it mistakenly thinks to be its business, or no reason at all?

\section{What Is This a Theory Of?}

Regardless of the interpretive question, if we are attracted to the Public Wrongs account, we have to figure out what to say about whether we should endorse Interpretation 2 or Interpretation 3.

In order to do so, I think we need a sense of what would follow, normatively, from violating Duff's principles. Let's say Duff's principles are a theory of 'just criminalization.' What is at stake here, then, is whether or not a community with a faulty civil order creates an unjust law. But in order to know what we think about this, we need to know what hangs on whether a law is deemed unjust or not.

If all that follows is that any criminalization that violated these Principles would be morally sub-optimal, then there is no reason not to shoot for very demanding principles. Go for Interpretation 2. It's demanding, to be sure, but a theory of morally perfect law ought to be demanding. Alternatively, if it follows that any such law would render any sanction that followed wrongful, we might want to be more cautious. Or if it follows that any such law would fail to be duty-generating, this might give us reason to be cautious, but in a different way. If you think laws can be morally imperfect but still legitimately enforceable, or duty-generating, then it matters whether a principle of criminalization is claiming to tell us what ideally we should criminalize, which criminal laws are legitimately enforceable, or which criminal laws are duty-generating. But Duff does not really engage with these questions. Since we don't have a sense of what follows from a law being outside the scope of Duff's theory, it is hard to know what the most plausible interpretation is.

To put the point another way, consider various objections to a decision of mine (for example, my choosing to spend some money on a sports car rather than give it to charity): you have no right - that money isn't yours to decide what to do with; it's impermissible to use your money in that way; that isn't the morally best way to use your money. These objections are importantly different. The same is true with objections to criminal law. In objecting to a criminal law, we might be saying to a society (or each other), this is morally not a good idea, you have no moral authority to make this law, or this is impermissible.

\footnotetext{
21 I am grateful to Antony Duff and Alec Walen for a fascinating email discussion of these questions, and regret that I don't have space to more fully pursue these issues here.
} 
Duff makes it clear that we can object to a civil order, but it isn't clear what (valid) objections of this sort amount to: do they render the laws unjust, illegitimate, unenforceable, or what? Relatedly, Duff wants to take account of the importance of democratic control in his principles of criminalization, but we can recognise that people have rights to control something (their money or their laws) but act impermissibly in doing so. We should only take account of democratic control in our principles, arguably, if violating the principles meant something like no obligation was generated, or we were morally unable to enforce the laws. So without knowing what follows from violating the principles, we don't really know how to interpret them, or whether we should agree with them.

\section{The Roles of Public Wrongs}

One of the principal virtues of The Realm of Criminal Law is it puts far more meat on the bones of the idea of a 'public wrong' and allows us to see how this idea works. There is also, I think, a greater sense of the idea's limitations-as Duff repeatedly acknowledges, it doesn't tell us much about what to criminalize, but it can help structure debate about what to criminalize.

So, we have a better idea about the content (and lack of content) of the idea of public wrongs. But here I want to talk about the role of this idea in this book. The idea of a public wrong seems to play three distinct roles in the book. One of those might give us cause for concern about circularity. The other two may give us cause for concern about what, precisely, the argument is for the public wrongs account.

These three roles that the idea of public wrongs plays are as follows. First, public wrongs are part of the 'rational reconstruction' of the criminal law we actually have. Duff states that our theorising about the criminal law must begin with an account of the criminal law as it exists. But this is not a purely descriptive task-we must look not only at what the criminal law is like, but at the values that it espouses and claims to embody. This in turn is not a neutral activity-it is a normatively driven process of 'rational reconstruction.' 22 And within the criminal law as we find it, once rationally reconstructed by Duff, we find a criminal law that is not a set of prohibitions, but a set of 'declarative definitions of those 'public' wrongs that are to be formally marked in this way. ${ }^{23}$ So, public wrongs are part of the law as reconstructed-our starting point.

The second role that the idea of a public wrong plays is as an account of the criminal law that is embedded in, and emerges from, a particular, liberal, republican, account of a polity and its civil order. The proper role for criminal law within a polity depends upon how that polity conceives of its civil order, and the role for the criminal law within that order. ${ }^{24}$ Therefore, the public wrongs account is one that emerges from a particular civil order: 'If... we portray criminal law... as an

\footnotetext{
22 Pp. 4-6; 12-13.

${ }^{23}$ P. 6. See also: pp. 27-28.

24 P. 182.
} 
institutional practice that functions primarily to define and declare a set of public wrongs...we are relying on a particular conception of civil order, as an order that requires or marks room for this kind of legal practice. ${ }^{25}$ That civil order is the liberal, republican order that Duff describes in chapter 5. That conception of the civil order is one which delivers us an understanding of criminal law that is based around public wrongs.

The third role that the idea of a public wrong appears to play is as a thin account of criminalization into which we can plug just about any account of the civil order. The idea of a public wrong here is not necessarily a liberal one, but a liberal civil order plus the public wrongs account will deliver us a liberal criminal law. On this view, Duff's account is not in competition with other theories of criminalizationhis purely formal theory is compatible with all of them, and there will be a theory of the civil order that justifies all of them. ${ }^{26}$

The difference between the second and third roles for the idea of public wrongs can perhaps be seen by seeing how the two different versions would treat Moorean expansive legal moralism. ${ }^{27}$ According to the second role, in which the public wrongs view of criminal law emerges from a liberal account of the civil order, expansive legal moralism is in competition with the public wrongs account. Liberals would not view their criminal law as appropriately dealing with all wrongdoing, and so would reject expansive legal moralism in favour of a public wrongs view of the criminal law. Sometimes Duff does indeed present expansive legal moralism as a competitor to the public wrongs account.

In contrast, according to the third role, in which the public wrongs account is an account into which we can plug different understandings of the civil order, expansive legal moralism is compatible with the public wrongs account, and is an interpretation of it, in a non-liberal setting. Non-liberal societies can say 'Round here all wrongdoing is our business. So all wrongs are public wrongs.' And that would be consistent with Duff's account.

I want to raise two potential worries here. The first is that Duff's search for the right account of criminalization begins with a 'rational reconstruction' of the criminal law; one that is explicitly not normatively neutral. ${ }^{28}$ But Duff says fairly little about what drives his decisions in interpreting the criminal law. He is up front that he is making such decisions, but not about how or why he is making them. Duff also says that he is not presupposing that the criminal law is justified-it remains to be seen whether the criminal law as described, interpreted, and reconstructed by Duff can be justified. However, we may well worry that if we are seeing whether and how the criminal law can be justified, and what kind of account of criminalization we

\footnotetext{
25 P. 183 . See also, p. 203, p. 213, and p. 185: "whether a polity will have any role at all for a system of criminal law, and what that role could be, will depend upon how criminal law is understood, and how the polity conceives its civil order'.

26 P. 258 .

27 M.S. Moore, Placing Blame: A Theory of Criminal Law (Oxford: Oxford University Press, 1997); M.S. Moore, 'Four Reflections on Law and Morality,' William \& Mary Law Review 48 (2007): 15231569.

28 P. 203.
} 
want, and our starting description of the criminal law contains the idea of public wrongs, then we only have two choices: endorse a theory of criminalization centred around public wrongs; or reject the criminal law altogether.

Presumably, Duff's defence of this would be that the initial characterisation of the criminal law is an initial sketch, and the later development of the view, from within the liberal republic civil order fleshes out that view. ${ }^{29}$ What we get then, is a kind of 'reflective equilibrium' - the idea of a criminal law based around 'public wrongs' is to be found both within the criminal law we have, and proceeds from an abstract account of a liberal republic polity.

However, it's not clear that we have really argued for the public wrongs account from either direction. The initial characterisation is a 'normatively driven', partial account of the criminal law. The liberal republic polity is described, not argued for, and it is made clear that it is but one form of civil order we might favour. What emerges, I think, is a coherent picture: the idea of a liberal republic produces an account of the criminal law which is based around the idea of public wrongs. That account is also one of the plausible interpretations we can offer of our own criminal law. But for those who don't buy the normatively laden interpretation, or the described liberal republic, there's nothing to offer them as a way into this circle.

The second worry is that it isn't clear how exactly liberal republicanism and the public wrongs account interact, and thus exactly what the argument for the public wrongs account is. Here is one version: we start with liberal republicanism, which is an attractive account of the civil order; and the best understanding of that civil order leads us to a 'public wrongs' understanding of the criminal law. Here is another: we argue for a 'public wrongs' understanding of the criminal law. There are a plurality of civil orders compatible with that understanding of the criminal law. Ideally, we would plug in a liberal republic account of the civil order, but others are available. Crucially, for this version of the argument to go through, the argument for the public wrongs account must be independent of the liberal republic account of the civil order. Duff, at various times, seem to gesture toward both of these arguments. The 'public wrongs' account seems to emerge from within the liberal republic, but the public wrongs account is supposed to be able to be 'filled in' with various different accounts of the civil order.

\section{Conclusion}

The Realm of Criminal Law does a lot to dispel previous unclarities about the public wrongs account. I now understand the account much better than I did previously. In assessing and developing the account further, we need to think about the following.

First, what is the relationship between the appropriate contents of the criminal law and our reasons for criminalizing conduct: even if criminalization is limited to public wrongs, are they the only reason to criminalize? Are they always a reason to

${ }^{29}$ P. 203: 'This argument will depend on, but also help to support, the [interpretive] account of criminal law I offered in Chapter 1'. 
criminalize? Second, given that not all public wrongs are to be criminalized, what kinds of reasons can or should be offered for or against criminalization and other forms of public response? These can't be public wrong-based. Third, what kind of account is the public wrongs account? What can be said about, and what follows normatively from, laws that violate the account? Is it an account of just laws, morally ideal laws, legitimate laws, or all of these? Fourth, and relatedly, is the 'public' in public wrongs normative, descriptive, or both? Fifth, how should we argue for the account? Does it proceed from a liberal republican political philosophy, or is that just one version of the public wrongs account, which has independent standing?

Open Access This article is distributed under the terms of the Creative Commons Attribution 4.0 International License (http://creativecommons.org/licenses/by/4.0/), which permits unrestricted use, distribution, and reproduction in any medium, provided you give appropriate credit to the original author(s) and the source, provide a link to the Creative Commons license, and indicate if changes were made.

Publisher's Note Springer Nature remains neutral with regard to jurisdictional claims in published maps and institutional affiliations. 